\title{
Clinical practice guidelines for the prevention and treatment of EGFR inhibitor-associated dermatologic toxicities
}

\author{
Mario E. Lacouture • Milan J. Anadkat • \\ René-Jean Bensadoun • Jane Bryce • Alexandre Chan • \\ Joel B. Epstein • Beth Eaby-Sandy • \\ Barbara A. Murphy • \\ MASCC Skin Toxicity Study Group
}

Received: 14 February 2011 /Accepted: 17 May 2011 / Published online: 1 June 2011

(C) Springer-Verlag 2011

\begin{abstract}
Background Epidermal growth factor receptor inhibitors (EGFRI) produce various dermatologic side effects in the majority of patients, and guidelines are crucial for the prevention and treatment of these untoward events. The purpose of this panel was to develop evidence-based recommendations for EGFRI-associated dermatologic toxicities. Methods A multinational, interdisciplinary panel of experts in supportive care in cancer reviewed pertinent studies using established criteria in order to develop first-generation recommendations for EGFRI-associated dermatologic toxicities.
\end{abstract}

The MASCC Skin Toxicity Study Group is composed of Andrei Barasch, Camilla Beder, Christine B. Boers-Doets, Tracey Doherty, Judith E. Raber-Durlacher, Dion Forstner, Seppo Langer, Judith Lees, and Dan Mellor.

Electronic supplementary material The online version of this article (doi:10.1007/s00520-011-1197-6) contains supplementary material, which is available to authorized users.

\footnotetext{
M. E. Lacouture $(\bowtie)$

Dermatology Service, Department of Medicine,

Memorial Sloan-Kettering Cancer Center,

Rockefeller Outpatient Pavilion Suite 228, 160 East 53rd Street,

New York, NY 10022, USA

e-mail: lacoutuM@mskcc.org
}

\section{J. Anadkat}

Washington University School of Medicine,

St. Louis, MO, USA

\section{R.-J. Bensadoun}

Centre Hospitalier Universitaire de Poitiers,

Poitiers Cedex, France

\section{J. Bryce}

Istituto Nazionale dei Tumori,

Naples, Italy
Results Prophylactic and reactive recommendations for papulopustular (acneiform) rash, hair changes, radiation dermatitis, pruritus, mucositis, xerosis/fissures, and paronychia are presented, as well as general dermatologic recommendations when possible.

Conclusion Prevention and management of EGFRI-related dermatologic toxicities is critical to maintain patients' health-related quality of life and dose intensity of antineoplastic regimens. More rigorous investigation of these toxicities is warranted to improve preventive and treatment strategies.
J. B. Epstein

University of Illinois at Chicago,

Chicago, IL, USA

B. Eaby-Sandy

University of Pennsylvania,

Philadelphia, PA, USA

B. A. Murphy

Vanderbilt University Medical Center,

Nashville, TN, USA 
Keywords Rash $\cdot$ Xerosis $\cdot$ Paronychia $\cdot$ Pruritus $\cdot$ Radiation dermatitis $\cdot$ Mucositis $\cdot$ EGFR inhibitors $\cdot$ Recommendations

\section{Background}

Overexpression of the epidermal growth factor receptor (EGFR) is strongly associated with cancer development and progression of a number of malignancies. EGFR inhibitors (EGFRI) are targeted agents used for treating lung (erlotinib), pancreatic (erlotinib in combination with gemcitabine), breast (lapatinib in combination with capecitabine or anastrozole), head and neck (cetuximab in combination with radiotherapy), and colorectal cancers (cetuximab, panitumumab) [1]. EGFRI may be used as first-line through third-line treatments, alone or in combination with other agents in the aforementioned cancers.

Commonly experienced dermatologic side effects include papulopustular (acneiform) rash, hair changes, radiation dermatitis enhancement, pruritus, mucositis, xerosis/ fissures, and paronychia. Incidences of these side effects are frequent and range from $36 \%$ for mucositis to $80 \%$ for papulopustular (acneiform) rash. Clinical presentation, incidence, impact on quality of life and cost, effect on EGFRI dosing, and risk factors for these toxicities have been described elsewhere [1]. When severe, dermatologic toxicities may to lead to dose modification or discontinuation by $36 \%$ and $72 \%$ of health care providers, respectively [2]. Although the side effect profile may be primarily dermatologic, toxicities result in significant physical and emotional discomfort, thus it is critical to maximize supportive measures.

Although most patients receiving EGFRIs experience these toxicities, few controlled studies have been conducted to determine the best practices for their management. Instead, much of the literature contains prevention and treatment recommendations based on case reports or studies with small samples sizes and nonrandomized patient allocation. In addition, available reports are beset with methodological issues including failure to adequately describe assessment tools or frequency, lack of validated tools for the assessment of dermatologic toxicities, and passive data collection. Given that these agents are relatively devoid of systemic and hematopoietic toxicities and have shown benefit in a variety of solid tumors, further large-scale studies to define best supportive care are necessary but are unlikely to become available in the foreseeable future. The purpose of this article is to provide comprehensive supportive care prevention and treatment recommendations for EGFRI-induced dermatologic toxicities based on the pertinent literature currently available. In cases where randomized clinical trials specific to EGFRI toxicities were not available, trials investigating phenotyp- ically similar dermatologic conditions were analyzed and reported.

\section{Methods}

\section{Participants}

The Multinational Association for Supportive Care in Cancer (MASCC) Skin Toxicity Study Group assembled an international, interdisciplinary group of experts in dermatology, medical and supportive oncology, health-related quality of life (HQOL), and pharmacovigilance. Topic review committees were formed according to expertise to review the literature and develop guidelines for the following dermatologic toxicities: papulopustular (acneiform) rash, hair changes, radiation dermatitis, pruritus, mucositis, xerosis/fissures, and paronychia.

\section{Recommendation development}

Each review committee consisted of three members with a primary reviewer to present the findings of the committee to the Skin Toxicity Study Group. Literature reviews were performed via databases such as Ovid MEDLINE (National Library of Medicine, Bethesda, MD, USA) and EMBASE (Elsevier B.V. Amsterdam, The Netherlands). Published literature as of November 2010 was included and each committee reviewed between 17 and 35 papers to formulate the recommended guidelines. Randomized clinical trials were considered the best source, and considerations for recommendations included Level of Evidence and Grade of Recommendation (Tables 1 and 2) [3]. In the absence of experimental evidence, pertinent studies and case reports were presented in conjunction with expert opinion derived from clinical practice. Recommendations were developed based on the presented findings and panel consensus. When available, data were extrapolated from other dermatologic conditions with similar clinical or pathologic characteristics (xerosis, alopecia and hirsutism, pruritus, paronychia, and radiation dermatitis).

Table 1 Levels of evidence [3]

Level I evidence is reserved for meta-analyses of randomized controlled trials or randomized trials with high power.

Level II evidence includes randomized trials with lower power.

Level III evidence includes nonrandomized trials, such as cohort or case-controlled series.

Level IV evidence includes descriptive and case studies.

Level V evidence includes case reports and clinical examples. 
Table 2 Recommendation grades [3]

Grade A is reserved for level I evidence or consistent findings from multiple studies of levels II, III, or IV evidence.

Grade B is for levels II, III, or IV evidence with generally consistent findings.

Grade $\mathrm{C}$ is similar to grade $\mathrm{B}$ but with inconsistencies.

Grade D implies little or no evidence.

\section{Results and recommendations}

Papulopustular (acneiform) rash

During the first weeks to months of EGFRI therapy, a papulopustular (acneiform) rash is the most clinically significant dermatologic toxicity. The rash usually develops in cosmetically sensitive areas, and it affects the majority of treated patients. Pruritic and tender erythematous papules and pustules develop in skin (Fig. 1a-c) with a high density of sebaceous glands (scalp, face, upper chest, and back). Histological analyses reveal a superficial inflammatory cell infiltrate surrounding hyperkeratotic or ectatic follicular infundibula or a florid neutrophilic suppurative folliculitis with rupture of epithelial lining. The rash is noteworthy for its impact on psychosocial well-being, related costs, secondary infections, and effects on dose intensity. As measured using Skindex-16, an HQOL tool used in dermatology, greater severity of rash will result in a greater decrement in HQOL, with emotions being the most important aspect of people's lives affected. Pain, burning, and irritation were common symptoms affecting the majority of patients [4]. Moreover, a survey of oncology practitioners demonstrated that $32 \%$ of providers discontinued therapy and $76 \%$ modified dose due to rash when severe [5].

Several factors have been associated with an increased risk of developing rash: for erlotinib, nonsmokers, people with fair skin, and older than 70; for cetuximab, male gender and those younger than 70. Moreover, severe rash is more frequent with monoclonal antibodies (10-17\%) than with low-molecularweight tyrosine kinase inhibitors (5-9\%). As with other toxicities, management can be preventive/prophylactic or treatment/reactive.

Randomized controlled trials for EGFRI rash have been conducted in the preventive/prophylactic setting, whereas uncontrolled reports reveal options for reactive treatment. Table 3 displays the recommendations for the prevention and treatment of papulopustular (acneiform) rash. Based on the high frequency of rash in EGFRI-treated patients and the consistent presentation within the first 2-4 weeks of therapy, preventive/prophylactic management is recommended unless there are contraindications based on patient and/or health care provider factors [6-12]. Hydrocortisone 1\% combined with moisturizer, sunscreen, and doxycycline $100 \mathrm{mg}$ bid for the first 6 weeks is recommended based on randomized data. Another study revealed that prophylactic minocycline $100 \mathrm{mg}$ daily is an effective agent in reducing the number of lesions during the first 8 weeks. Doxycycline appears to have a more favorable safety profile, especially in patients with renal dysfunction, whereas minocycline is less photosensitizing, thus preferable in geographic or seasonal locations with a high UV index.

Reactive use of medium- to high-potency topical corticosteroids is recommended based on studies showing in vitro release of inflammatory chemokines after EGFRI therapy. Vitamin K3 (menadione) is currently being investigated, but published reports on vitamin $\mathrm{K} 1$ are based on studies without control groups [13, 14]. Similarly, studies investigating isotretinoin for the treatment of EGFRI-induced rash have not included control groups, but consistent reports of isotretinoin at doses lower than those used for acne support the recommendation of their use when other measures have failed. Additional support for isotretinoin is provided by patient reports of improved HQOL, and there is evidence of clinical response to the EGFRI [1, 15-17]. Although the rash peaks in weeks 4-6 after EGFRI initiation and decreases in severity after weeks 6-8, postinflammatory skin alterations (erythema and hyperpigmentation) are longterm sequelae that can last for months or years. Therefore, prophylactic strategies are important, and appropriate medication (Table 3) should be considered throughout EGFRI treatment and follow-up in order to minimize these late effects.

\section{Hair changes}

A variety of hair changes have been described in patients taking EGFRI and include trichomegaly (elongation and curling of the eyelashes), hypertrichosis often presenting as facial hirsutism, and scalp hair changes ranging from brittleness and slowed growth to alopecia. Nonscarring alopecia occurs after 2-3 months of therapy and may present as frontal or patchy patterns, with a tendency to progress to diffuse alopecia with prolonged EGFRI therapy, which may resolve spontaneously in some patients. Alopecia generally resolves after discontinuation of therapy, though hair regrowth may be of varying quality. No interventions to reduce or prevent nonscarring alopecia in these patients have been published in the literature, and recommended interventions are supportive (education, cosmetic approaches for patient comfort) and based on studies in androgenetic (male-pattern) and female alopecia (Table 4).

Minoxidil has been found effective for treating nonscarring alopecia in the general patient population [18-20]. In two studies, males' subjective reporting of increased hair growth was statistically significant for both the $2 \%$ and $5 \%$ 
Fig. 1 a Mild papulopustular (acneiform) rash, b and $\mathbf{c}$ papulopustular (acneiform) rash, d and $\mathbf{e}$ radiation dermatitis, $\mathbf{f}$ and $\mathbf{g}$ mucositis, $\mathbf{h}$ fingertip fissure, and $\mathbf{i}$ paronychia
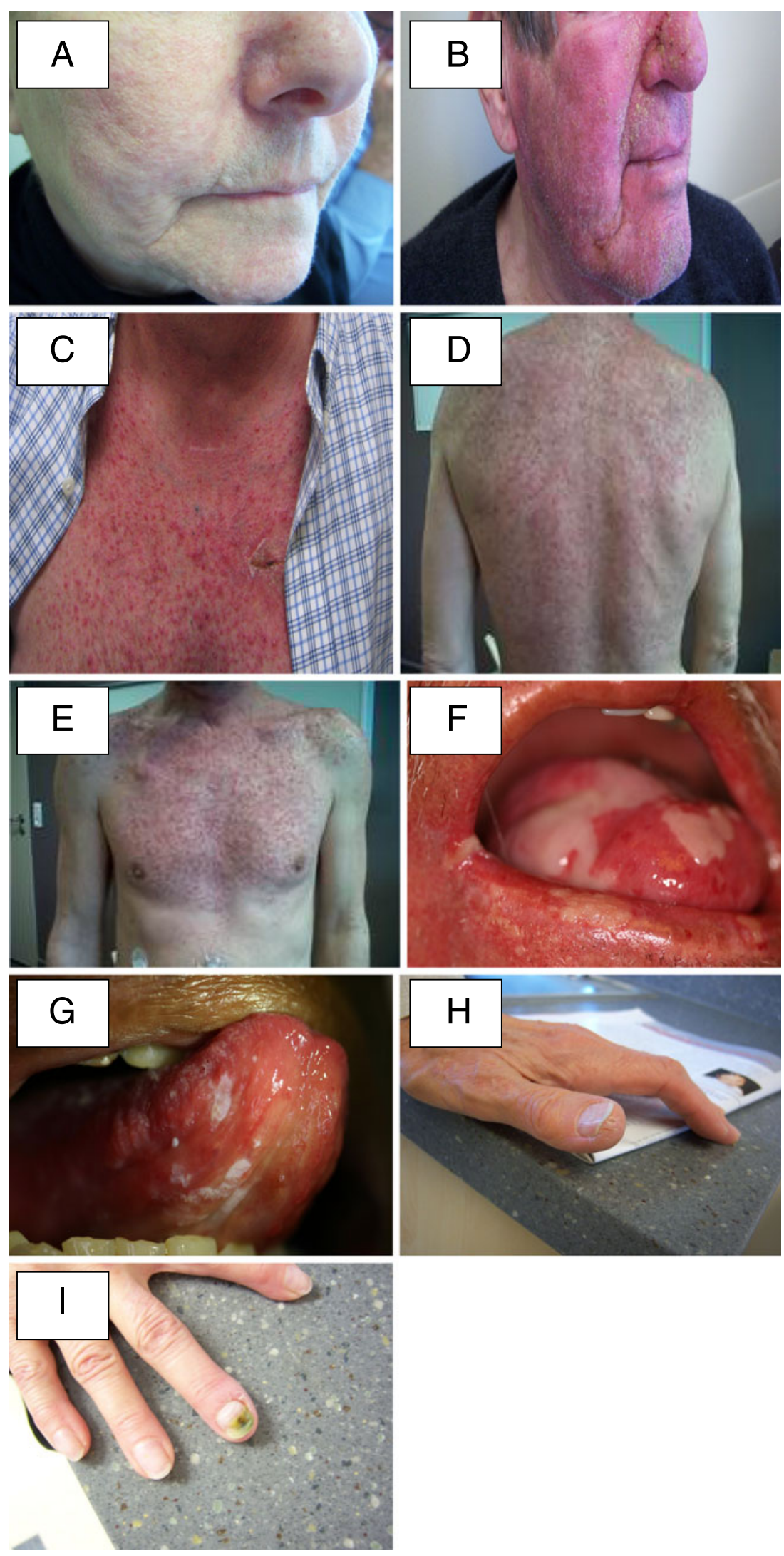
Table 3 Papulopustular (acneiform) rash recommendations

\begin{tabular}{|c|c|c|c|c|c|}
\hline & Recommend & Not recommended & $\begin{array}{l}\text { Level of } \\
\text { evidence }\end{array}$ & $\begin{array}{l}\text { Recommendation } \\
\text { grades }\end{array}$ & Comments \\
\hline \multicolumn{6}{|c|}{ Preventive (weeks $1-6$ and 8 of EGFRI initiation) } \\
\hline Topical & $\begin{array}{l}\text { Hydrocortisone } 1 \% \text { cream } \\
\text { with moisturizer and } \\
\text { sunscreen twice daily }\end{array}$ & $\begin{array}{l}\text { Pimecrolimus } \\
1 \% \text { cream } \\
\text { Tazarotene } \\
0.05 \% \text { cream } \\
\text { Sunscreen as } \\
\text { single agent }\end{array}$ & $\mathrm{II}^{\mathrm{a}}$ & $\mathrm{C}$ & \\
\hline Systemic & $\begin{array}{l}\text { Minocycline } \\
100 \mathrm{mg} \text { daily } \\
\text { Doxycycline } 100 \mathrm{mg} \text { bid }\end{array}$ & $\begin{array}{l}\text { Tetracycline } \\
500 \mathrm{mg} \text { bid }\end{array}$ & $\mathrm{II}^{\mathrm{a}}$ & A & $\begin{array}{l}\text { Doxycycline is preferred } \\
\text { in patients with renal } \\
\text { impairment. Minocycline } \\
\text { is less photosensitizing. }\end{array}$ \\
\hline \multicolumn{6}{|c|}{ Treatment } \\
\hline Topical & $\begin{array}{l}\text { Alclometasone } \\
0.05 \% \text { cream } \\
\text { Fluocinonide } \\
0.05 \% \text { cream bid } \\
\text { Clindamycin } 1 \%\end{array}$ & Vitamin K1 cream & $\mathrm{IV}^{\mathrm{a}}$ & $\mathrm{C}$ & \\
\hline Systemic & $\begin{array}{l}\text { Doxycycline } 100 \mathrm{mg} \text { bid } \\
\text { Minocycline } 100 \mathrm{mg} \text { daily } \\
\text { Isotretinoin at low doses } \\
(20-30 \mathrm{mg} / \text { day })\end{array}$ & Acitretin & $\mathrm{IV}^{\mathrm{a}}$ & $\mathrm{C}$ & Photosensitizing agents \\
\hline
\end{tabular}

${ }^{\text {a }}$ EGFRI study

minoxidil groups versus placebo and objective hair counts also were significantly higher in the two treatment groups $[18,19]$. Similar findings were reported in one study with females randomized to the same two treatment groups versus placebo group for hair count, although no difference was found between the groups for subjective reporting of increased hair changes [20]. Higher incidences of pruritus and hypertrichosis were reported in the minoxidil $5 \%$ group than in the $2 \%$ group $[18,19]$. These should be monitored if minoxidil is prescribed for patients receiving EGFRIs as these also are possible skin toxicities associated with the EGFRI therapy.

Scarring alopecia also has been reported in these patients and is consequent to scalp, facial, and chest lesions that can lead to permanent hair loss. Prevention and management strategies, based on expert opinion, aim to reduce inflammation and scarring for patients receiving EGFRI therapy. Options include topical hydrocortisone $0.2 \%$, steroid shampoos, and class 1 steroid lotions [21]. Use of bath oils or mild shampoo followed by antibiotic spray has been recently reported [22]. Preventive strategies for reducing papulopustular (acneiform) rash severity, as described above, also should be employed to minimize scarring alopecia.

Facial hypertrichosis (hirsutism) and trichomegaly appear after the first 1-2 months of therapy, and these symptoms do not wane over time; instead, they tend to persist for the duration of therapy with EGFRIs. Unwanted or excess facial hair may be treated with temporary or permanent hair removal. Trichomegaly is associated with patient discomfort and the abnormal eyelash growth can lead to corneal abrasions and further ocular complications. Trichomegaly can be treated with lash clipping every 2-4 weeks, and referral to an ophthalmologist is indicated for patients with irritation or persistent discomfort. Topical eflornithine cream has been well tolerated and efficacious for the treatment of hirsutism in open-label trials with the general female population and has been found to significantly improve HQOL in a randomized clinical trial $[23,24]$. Laser hair removal has been shown to reduce hair growth in a small sample [25], but eflornithine plus laser hair removal has been reported to be more effective than laser hair removal alone in randomized trials with the general population [26, 27]. Amelioration of symptoms, patient education, and support are recommended for patients with hair changes so that EGFRI therapy may continue.

\section{Radiation dermatitis}

The development of some degree of radiation dermatitis is considered inevitable for the majority of patients receiving 
Table 4 Hair changes recommendations

\begin{tabular}{|c|c|c|c|c|c|}
\hline & Recommend & Not recommended & $\begin{array}{l}\text { Level of } \\
\text { evidence }\end{array}$ & $\begin{array}{l}\text { Recommendation } \\
\text { grades }\end{array}$ & Comments \\
\hline \multicolumn{6}{|c|}{ Preventive hair loss } \\
\hline Topical & $\begin{array}{l}\text { For scarring alopecia, follow } \\
\text { rash recommendations }\end{array}$ & $\begin{array}{l}\text { Preventive interventions for } \\
\text { nonscarring alopecia }\end{array}$ & $\mathrm{V}$ & $\mathrm{D}$ & \\
\hline Systemic & $\begin{array}{l}\text { For scarring alopecia, follow } \\
\text { rash recommendations }\end{array}$ & $\begin{array}{l}\text { Preventive interventions for } \\
\text { nonscarring alopecia }\end{array}$ & $\mathrm{V}$ & $\mathrm{D}$ & \\
\hline \multicolumn{6}{|c|}{ Treatment hair loss } \\
\hline Topical & $\begin{array}{l}\text { Nonscarring } \\
\text { Minoxidil } 2 \%, 5 \% \text { bid } \\
\text { Scarring } \\
\text { Class } 1 \text { steroid lotion, } \\
\text { shampoo, or foam } \\
\text { Antibiotic lotion }\end{array}$ & & $\begin{array}{c}\mathrm{I}^{\mathrm{a} / \mathrm{II} / \mathrm{III} /} \\
\mathrm{IV}^{\mathrm{b}}\end{array}$ & $\mathrm{B} / \mathrm{D}$ & $\begin{array}{l}\text { Consensus } \\
\text { of experts }\end{array}$ \\
\hline \multicolumn{6}{|c|}{ Preventive increased hair } \\
\hline & Patient education and support & & IV & $\mathrm{B}$ & $\begin{array}{l}\text { Consensus } \\
\text { of experts }\end{array}$ \\
\hline \multicolumn{6}{|c|}{ Treatment increased hair } \\
\hline $\begin{array}{l}\text { Facial } \\
\text { hypertrichosis }\end{array}$ & $\begin{array}{l}\text { Eflornithine } \\
\text { Lasers }\end{array}$ & Waxing, chemical depilatories & $\mathrm{IV}^{\mathrm{b}}, \mathrm{II}^{\mathrm{a}}$ & $\mathrm{B}$ & $\begin{array}{l}\text { Consensus of } \\
\text { experts }\end{array}$ \\
\hline $\begin{array}{l}\text { Eyelash } \\
\text { trichomegaly }\end{array}$ & Eyelash trimmings regularly & & IV & $\mathrm{B}$ & \\
\hline
\end{tabular}

${ }^{a}$ Non-EGFRI noncancer treatment study

${ }^{\mathrm{b}}$ EGFRI study

radiotherapy due to direct injury to epidermal basal cells and connective tissue changes that usually develop within the first few weeks of radiation initiation. Furthermore, higher incidence of high-grade radiation dermatitis results from the addition of EGFRIs to radiotherapy [28]. Radiation dermatitis ranges from erythema and dry or wet desquamation to skin necrosis or ulceration of full thickness dermis with spontaneous bleeding from the involved site (Fig. 1d, e).

The establishment of a proper technique to minimize the dose delivered to the epidermis and a quality assurance program for radiotherapy planning and delivery is critical not only in therapeutic terms but also from the perspective of avoiding unnecessary skin toxicity. A primary step in the management of radiation dermatitis of any severity is to establish that the skin reactions are not a result of any concomitant medication, other than EGFRI. In the case of more severe skin reactions, correct radiation dose and distribution should be verified.

Table 5 displays the recommendations for the prevention and treatment of radiation dermatitis. An important step in managing and treating radiation dermatitis is to keep the irradiated area clean and dry, even when ulcerated. Gentle washing and drying of the skin within the radiation portal have been shown to reduce the acute radiotherapy- associated skin reactions in patients receiving radiotherapy for breast cancer and is now routinely recommended for all patients receiving radiotherapy [29, 30]. A number of topical agents can be considered, all of which are considered high-potency topical corticosteroids (mometasone, methylprednisolone, beclomethasone, and betamethasone creams $[31,32]$.

The recently reported results of Radiation Therapy Oncology Group trials (99-13) in patients with squamous cell carcinoma of the head and neck failed to show any benefit of the systematic use of interventional or prophylactic trolamine emulsion in reducing skin toxicity [33]. Another study showed no significant benefit of pentoxifylline prophylaxis on the development of acute skin reactions [34]. The potential benefit of oral zinc supplementation in postponing the development of severe mucositis and dermatitis and in alleviating the degree of mucositis and dermatitis in patients receiving radiotherapy for cancers of the head and neck [35] warrants additional confirmatory studies.

Where infection is suspected, the treating physician should use best clinical judgment for management, including considering swabbing the affected area for identification of the infectious agent. In patients for whom skin infection is suspected or documented, the neutrophil count 
Table 5 Radiation dermatitis recommendations

\begin{tabular}{|c|c|c|c|c|c|}
\hline & Recommend & Not recommended & $\begin{array}{l}\text { Level of } \\
\text { evidence }\end{array}$ & $\begin{array}{l}\text { Recommendation } \\
\text { grades }\end{array}$ & Comments \\
\hline \multicolumn{6}{|c|}{ Preventive } \\
\hline Topical & $\begin{array}{l}\text { Maintain hygiene, gently clean and } \\
\text { dry skin in the radiation field, } \\
\text { shortly before radiation treatment }\end{array}$ & $\begin{array}{l}\text { Moisturizers, gels, emulsions, } \\
\text { and dressings should not be } \\
\text { applied shortly before RT }\end{array}$ & $\mathrm{IV}^{\mathrm{a}}$ & A & \\
\hline Topical & High-potency topical steroids & Trolamine LED (photons) & $\mathrm{I}^{\mathrm{a}}$ & A & \\
\hline Systemic & & $\begin{array}{l}\text { Pentoxifylline/zinc } \\
\text { supplementation }\end{array}$ & $\mathrm{II}^{\mathrm{a}} / \mathrm{V}^{\mathrm{a}}$ & $\mathrm{B} / \mathrm{D}$ & $\begin{array}{l}\text { Consensus of experts: no } \\
\text { systemic treatment in } \\
\text { the preventive setting }\end{array}$ \\
\hline \multicolumn{6}{|l|}{ Treatment } \\
\hline Topical & $\begin{array}{l}\text { Maintain hygiene and gently clean } \\
\text { and dry skin in the radiation field, } \\
\text { even when ulcerated }\end{array}$ & Hyaluronic acid cream & IV & $\mathrm{A}$ & Consensus of experts \\
\hline Topical & $\begin{array}{l}\text { Moisturizers/antibacterial } \\
\text { moisturizers }\end{array}$ & $\begin{array}{l}\text { Anti-inflammatory } \\
\text { emulsion (trolamine) }\end{array}$ & $\mathrm{IV}^{\mathrm{a}} / \mathrm{V}^{\mathrm{b}}$ & $\mathrm{B} / \mathrm{C}$ & Consensus of experts \\
\hline Topical & $\begin{array}{l}\text { Drying gels } \\
\text { Antiseptics (chlorhexidine) }\end{array}$ & & $\mathrm{IV}^{\mathrm{b}}$ & $\mathrm{B}$ & Consensus of experts \\
\hline Topical & Hydrophilic dressings & & $\mathrm{V}^{\mathrm{b}}$ & $\mathrm{D}$ & \\
\hline Topical & $\begin{array}{l}\text { Antibiotics when infection is } \\
\text { suspected }\end{array}$ & & $\mathrm{IV}^{\mathrm{a}}$ & $\mathrm{B}$ & Consensus of experts \\
\hline Systemic & Antibiotics: doxycycline & & $\mathrm{II}^{\mathrm{c}}$ & $\mathrm{B}$ & Consensus of experts \\
\hline Others & $\begin{array}{l}\text { Blood cultures should be carried out } \\
\text { if fever and/or signs of sepsis }\end{array}$ & & $\mathrm{I}^{\mathrm{b}}$ & A & \\
\hline
\end{tabular}

${ }^{\mathrm{a}}$ Non-EGFRI cancer treatment study

${ }^{\mathrm{b}}$ Non-EGFRI noncancer treatment study

${ }^{\mathrm{c}}$ EGFRI study

also should be checked, especially if the patient is receiving concomitant chemotherapy. Indeed, severe desquamation is associated with a risk of septicemia. Blood cultures should also be carried out if additional signs of sepsis and/or fever are present, particularly if the neutrophil count is low.

Where there is coexistence of radiation dermatitis and EGFRI-related papulopustular (acneiform) rash within an irradiated field, management depends on the severity of radiation dermatitis. Prophylactic therapy directed against the radiation dermatitis (with high-potency topical corticosteroids) and an oral antibiotic (doxycycline or minocycline) for the EGFRI rash should be considered. For mild radiation dermatitis, it is prudent to follow the published findings on the management of EGFRI-related papulopustular (acneiform) rash outside irradiated fields [35-37]. For moderate-severe radiation dermatitis, it is important to investigate for possible secondary Staphylococcus aureus infection.

\section{Pruritus}

Pruritus occurs in approximately half of all EGFRI-treated patients, and although it rarely requires dose modifications or discontinuation of drug therapy, it can have dramatic impact upon the patient's HQOL. It is important to note that the occurrence of pruritus often accompanies papulopustular (acneiform) rash at onset; hence, it is important to emphasize that appropriate treatment of underlying rash also can alleviate the pruritic symptoms. Because itching can also occur as a consequence of dry skin, it is important to ensure adequate measures are provided to prevent dryness (see the "Xerosis and fissures" section).Currently, the mechanism of action behind pruritus induced by EGFRIs is not clearly elucidated. Histamine, which is released by mast cells in persons with urticaria, is classically associated with pruritus. It is unknown whether other neurotransmitters or receptors (including serotonin, opioids, and gamma-aminobutyric acid) explain the pruritus that is experienced by patients treated with EGFRIs.

In the literature, no clinical studies are designed to study specific primary endpoints to evaluate the most optimal therapy for EGFRI-induced pruritus. Hence, much of the data originated from case series as well as case reports on various agent approaches for pruritus relief. However, a number of clinical management guidelines have provided insights how EGFRI-induced pruritus should be managed $[38,39]$. Table 6 displays the recommendations for the treatment of pruritus. 
Table 6 Pruritus recommendations

\begin{tabular}{|c|c|c|c|c|c|}
\hline & Recommend & $\begin{array}{l}\text { Not } \\
\text { recommended }\end{array}$ & $\begin{array}{l}\text { Level of } \\
\text { evidence }\end{array}$ & $\begin{array}{l}\text { Recommendation } \\
\text { grades }\end{array}$ & Comments \\
\hline \multicolumn{6}{|l|}{ Preventive } \\
\hline Topical & Gentle skin care instructions & & $I V^{a, b}$ & $\mathrm{D}$ & Consensus of experts \\
\hline Systemic & & Steroids & $\mathrm{IV}^{\mathrm{a}, \mathrm{b}}$ & $\mathrm{D}$ & Consensus of experts \\
\hline \multicolumn{6}{|l|}{ Treatment } \\
\hline Topical & $\begin{array}{l}\text { Menthol } 0.5 \% \text {-pramoxine } 1 \% \text {-doxepin } \\
\text { Medium- to high-potency steroids } \\
\text { (triamcinolone acetonide } 0.025 \% \text {; desonide } \\
0.05 \% \text {; fluticasone proprionate } 0.05 \% \text {; } \\
\text { alclometasone } 0.05 \% \text { ) }\end{array}$ & & $\mathrm{III}^{\mathrm{b}}$ & $\mathrm{B}$ & $\begin{array}{l}\text { Treat underlying condition } \\
\text { first (rash, xerosis) }\end{array}$ \\
\hline Topical & & $\begin{array}{l}\text { Antihistamines } \\
\text { Lidocaine }\end{array}$ & II $^{\mathrm{b}}$ & $\mathrm{C}$ & $\begin{array}{l}\text { These agents can become } \\
\text { allergens, and can be } \\
\text { absorbed systemically }\end{array}$ \\
\hline Systemic & Antihistamines $^{\mathrm{b}}$ & & $\mathrm{I}^{\mathrm{c}}$ & A & $\begin{array}{l}\text { Nonsedating first; some may } \\
\text { need adjustment for renal } \\
\text { impairment }\end{array}$ \\
\hline Systemic & & Aprepitant $\mathrm{t}^{\mathrm{a}}$ & $V^{a}$ & $\mathrm{D}$ & \\
\hline Systemic & Gabapentin/pregabalin ${ }^{\mathrm{a}}$ & & $\mathrm{V}^{\mathrm{b} / \mathrm{a}}$ & $\mathrm{D}$ & $\begin{array}{l}\text { Recommended as second-line } \\
\text { treatment only if } \\
\text { antihistamines fail }\end{array}$ \\
\hline Systemic & Doxepin & & $\mathrm{V}^{\mathrm{a}}$ & $\mathrm{D}$ & \\
\hline
\end{tabular}

${ }^{\mathrm{a}}$ EGFRI study

${ }^{\mathrm{b}}$ Non-EGFRI noncancer treatment study

${ }^{\mathrm{c}}$ Non-EGFRI cancer treatment study

In general, antihistamines have been used to provide symptom relief to patients with mild to moderate pruritus of various etiologies. Data in the setting of EGFRI is limited and conflicting. In one study, two patients were given loratadine for 14 days; however, patients did not find it useful and discontinued treatment [22]. Thus, pharmacologic guidance must be sought from trials conducted in other patient populations.

In another study, a second-generation antihistamine (loratadine) was shown to be equally effective as hydroxyzine (a first-generation antihistamine) in patients with chronic idiopathic urticaria and atopic dermatitis. Moreover, loratadine is not associated with sedative side effects that are commonly observed with hydroxyzine. One study has demonstrated that somnolence or sedation was recorded in $5 \%$ of loratadine patients and $40 \%$ of hydroxyzine patients after 1 week of drug usage [40]. Another study involving loratadine and hydroxyzine demonstrated similar results. The efficacy is similar between treatment groups, but patients treated with loratadine had significantly less $(p<0.01)$ sedation and dry mouth compared to patients treated with hydroxyzine [41]. Hence, nonsedating second-generation antihistamines are recommended as the first approach for systemic therapy for pruritus during daytime. Dosing of antihistamines also should be kept to the minimum to avoid adverse drug reactions, particularly in the elderly, as these medications may cause severe anticholinergic reactions. For patients who suffer from pruritus during nighttime, firstgeneration antihistamines (such as diphenhydramine and hydroxyzine) are preferable given their sedative properties.

Antiepileptic agents, such as pregabalin and gabapentin, are reported to provide pruritic relief in the general patient population. It was suggested that pregabalin is capable of relieving pruritus centrally and peripherally by reducing the release of calcitonin gene-related peptide, which is a mediator of itching in the periphery, as well as modification of central perception of itch by a modulation of $\mu$-opioid receptors centrally [42]. The efficacy of gabapentin to reduce pruritus associated with burns or with renal failure was reported in trials of gabapentin alone or with various antihistamines [43, 44]. However, data in the setting of EGFRI-associated pruritus is based on small case series [42]. In summary, these antiepileptic agents should only be recommended as secondline treatment in patients who failed antihistamines and therapies against underlying rash and/or xerosis and continue to experience clinically significant pruritus. Recently, aprepitant, an NK-1 antagonist was reported to reduce pruritus that is caused by erlotinib [38]. However, caution must be taken as aprepitant may cause drug-drug interactions and potentially affect the concentrations of erlotinib [45].

A number of over-the-counter topical agents are available for pruritus reduction. Menthol, a naturally occurring 
cyclic terpene alcohol of plant origin, is frequently used as an antipruritic at concentrations of $1-3 \%$. It has been shown that menthol elicits the same cooling sensation as low temperature through the TRPM8 receptor. Skin cooling has been demonstrated to provide therapeutic relief in patients who experience pruritus. Menthol is a benign agent with minimal side effects which can be used concurrently with systemic agents to relieve rash and itch [46]. Topical and oral doxepin have been found to relieve pruritus in the general patient population [47-49]. At this time, it is unknown whether other topical agents, such as antihistamines, lidocaine, and calamine, will provide adequate efficacy to alleviate pruritus induced by EGFRIs. In the literature, topical antihistamines produce mixed efficacy results, as reported in a recent review [50]. Furthermore, these agents are known to be sensitizers, which may further induce secondary allergic contact dermatitis after long-term usage of these agents [51]. Hence, we recommend against routine usage of these agents to manage EGFRIinduced pruritus.

\section{Oral complications}

Oral complications reported in EGFRI-treated patients are infrequent. The most commonly reported oral complication is mucositis. Oral mucositis may present with broad areas of erythema, aphthous-like stomatitis, or superimposed upon those of radiation and conventional chemotherapy [52] (Fig. 1f, g). Severe mucositis is uncommon with single-agent therapy; however, in combination with other cytotoxic chemotherapy or radiation, severe and prolonged mucositis may be seen. The pathobiology of EGFRIassociated mucositis has yet to be elucidated. Other oral side effects including taste change and salivary changes have not been specifically reported. Sporadic patient selfreporting indicates that other oral complications may be underreported [53-61]. EGFRIs are commonly used in combination with either chemotherapy or radiation therapy (in the head and neck patient population). EGFRI-associated mucositis may occur independent of or additive to oral complications associated with radiation therapy and conventional cytotoxic chemotherapy.

There are no trials investigating the management of EGFRI-associated mucositis, thus guidance for prevention and treatment was informed by current approaches to the management of cytotoxic chemotherapy and radiation therapy-induced mucositis as described in the MASCC guidelines [62, 63]. Table 7 displays the recommendations for the prevention and treatment of oral complications. The approach recommended includes the foundation of (1) thorough oral care, (2) aggressive pain management, (3) adequate nutritional support, (4) radiation treatment planning that optimizes therapeutic index, and (5) benzydamine rinse (not available in the USA) for radiation mucositis.
Oral health should be assessed prior to treatment and a plan of care developed and implemented for individual patients. Oral health status and oral care should be evaluated periodically during treatment as well as after the completion of therapy. Mucositis-associated pain should be aggressively managed with topical analgesics and systemic analgesics as needed. As mucosal pain has both nociceptive and neuropathic components, opioids and adjuvant medications should be considered [64]. Nutrient and calorie support of patients during and following cancer therapy is strongly supported.

Many preventive and treatment strategies have been investigated for oral mucositis; unfortunately, few have been found to be efficacious (see the MASCC guidelines for specific agents that have failed to demonstrate efficacy). Diagnosis of contributing oral infections such as candidiasis, herpes virus reactivation, and mucositis allow for specific intervention. Other approaches to EGFRI dermatologic toxicities are reported in this paper and some may have application for the management of oral mucositis. For example, minocycline and doxycycline have been studied for the management of oral aphthous lesions $[65,66]$ and the study of their potential application in the management of mucositis associated with targeted therapies may be indicated. Dermatitis is also managed with steroids, and while use of steroids increases risk of secondary oral infection (e.g., candidiasis), this may be managed with currently available azole antifungals, although further study is needed.

\section{Xerosis and fissures}

Abnormal keratinocyte differentiation due to EGFRIs leads to a deteriorated stratum corneum with a decrease in loricrin, which is the main protein holding together the scaffolding of the epidermis $[67,68]$. This process results in an unwoven epidermal layer that cannot preserve moisture, thus resulting in xerosis. Xerosis often is referred to as dry skin or cutaneous dryness, which can turn into xerotic dermatitis (asteatotic eczema), an inflammation resulting from dry skin. It generally has a later onset, around 30-60 days or more into EGFRI treatment, and often accompanies or succeeds the papulopustular (acneiform) rash [22, 68]. Age, preexisting eczema, and prior treatment with cytotoxics pose a greater risk of xerosis [36, 67, 69].

To date, there are no existing randomized clinical trials assessing the prevention or treatment of EGFRI-induced xerosis. Table 8 displays the recommendations for the prevention and treatment of xerosis. Preventive strategies start with bathing techniques. Avoiding bathing in excess and using tepid water as opposed to hot water is recommended. When bathing, patients should be advised to use bath oils or mild moisturizing soaps that are free of 
Table 7 Oral complications recommendations

\begin{tabular}{|c|c|c|c|c|c|}
\hline & Recommend & Not recommended & $\begin{array}{l}\text { Level of } \\
\text { evidence }\end{array}$ & $\begin{array}{l}\text { Recommendation } \\
\text { grades }\end{array}$ & Comments \\
\hline \multicolumn{6}{|l|}{ Preventive } \\
\hline Topical & $\begin{array}{l}\text { Benzydamine } \\
\text { (not FDA approved) }\end{array}$ & $\begin{array}{l}\text { Antimicrobials } \\
\text { (chlorhexidine, lozenges) }\end{array}$ & $\mathrm{II}^{\mathrm{a}}$ & $\mathrm{B}$ & $\begin{array}{l}\text { Studied in radiation therapy } \\
\text { alone; not available } \\
\text { in USA }\end{array}$ \\
\hline Topical & Steroids & & $\mathrm{III}^{\mathrm{b}}$ & $\mathrm{B}$ & $\begin{array}{l}\text { For EGFRI dermatitis; } \\
\text { consensus of experts }\end{array}$ \\
\hline Topical & Cryotherapy (ice chips) & & $\mathrm{I}^{\mathrm{a}}$ & A & $\begin{array}{l}\text { For short half-life bolus } \\
\text { chemotherapy }\end{array}$ \\
\hline Topical & Low-level laser therapy & & $\mathrm{II}^{\mathrm{a}}$ & $\mathrm{B}$ & $\begin{array}{l}\text { Suggested; more } \\
\text { studies needed }\end{array}$ \\
\hline Topical & & $\begin{array}{l}\text { Azelastine, chamomile, coating } \\
\text { agents, traumeel, tretinoin } \\
\text { cream }\end{array}$ & $\mathrm{III}^{\mathrm{a}}$ & $\mathrm{C}$ & $\begin{array}{l}\text { Insufficient evidence } \\
\text { for guideline }\end{array}$ \\
\hline Systemic & $\begin{array}{l}\text { Patient-controlled } \\
\text { analgesia for oral } \\
\text { mucositis pain }\end{array}$ & $\begin{array}{l}\text { Antimicrobials (antiviral, } \\
\text { antifungal, antibacterial) }\end{array}$ & $\mathrm{II}^{\mathrm{a}}$ & $\mathrm{B}$ & Consensus of experts \\
\hline Systemic & & Palifermin (Kepivance) & $\mathrm{I}^{\mathrm{a}}$ & A & $\begin{array}{l}\text { Recommended for } \\
\text { autologous HCT only }\end{array}$ \\
\hline Systemic & & Pentoxifylline & $\mathrm{II}^{\mathrm{a}}$ & $\mathrm{B}$ & Not recommended in HCT \\
\hline Miscellaneous & Radiation blocks, IMRT & & $\mathrm{IV}^{\mathrm{a}}$ & $\mathrm{D}$ & $\begin{array}{l}\text { Consensus of opinion with } \\
\text { radiation therapy }\end{array}$ \\
\hline \multicolumn{6}{|l|}{ Treatment } \\
\hline Topical & & $\begin{array}{l}\text { Coating agents } \\
\text { Antimicrobials (chlorhexidine) }\end{array}$ & $\mathrm{II}^{\mathrm{a}}$ & $\mathrm{B}$ & $\begin{array}{l}\text { Insufficient evidence for } \\
\text { guidelines; consensus } \\
\text { of experts }\end{array}$ \\
\hline Topical & & $\begin{array}{l}\text { Steroids } \\
\text { Traumeel } \\
\text { Tretinoin } \\
\text { Nonsteroidals } \\
\text { Prostaglandin }\end{array}$ & $\mathrm{III}^{\mathrm{a}}$ & $\mathrm{D}$ & $\begin{array}{l}\text { Insufficient evidence for } \\
\text { guidelines; consensus of } \\
\text { experts }\end{array}$ \\
\hline Topical & & $\begin{array}{l}\text { Hematopoietic growth factors } \\
\text { (GCSF, GMCSF) }\end{array}$ & $\mathrm{III}^{\mathrm{a}}$ & $\mathrm{B}$ & Not recommended \\
\hline Systemic & $\begin{array}{l}\text { Antibiotics (radiation and } \\
\text { EGFRI dermatitis) } \\
\text { Doxycycline }\end{array}$ & Pentoxifylline & $\mathrm{II}^{\mathrm{b}} / \mathrm{II}^{\mathrm{a}}$ & $\mathrm{B}$ & Consensus of experts \\
\hline
\end{tabular}

${ }^{a}$ Non-EGFRI cancer treatment study

${ }^{\mathrm{b}}$ EGFRI study

fragrances or perfumes. Avoiding extreme temperatures, such as severe cold, dry weather or significant heat, and direct sun exposure, which can cause sunburns, is also recommended [70]. Patients should refrain from using alcoholcontaining lotions or skin products that may dehydrate skin $[36,38,71]$.

Treatment of mild or moderate xerosis consists of thick moisturizing creams without fragrances or potential irritants. Moisturizers should be occlusive, emollient creams that are generally packaged in a jar or tub rather than a lotion that can be pumped or poured. Specific creams can include urea, colloidal oatmeal, and petroleum-based creams. For scaly areas of xerosis, ammonium lactate or lactic acid creams can be utilized. Greasy creams may be used on the limbs for better control of xerosis but are cautioned on the face and chest, along with extremely hairy sites, due to risk for folliculitis secondary to occlusion $[36,38]$. For more severe xerosis causing inflammation with or without eczema, topical steroid creams may be necessary. Topical retinoids and benzoyl peroxide gels are not recommended due to their drying effect [38, 70, 72].

Skin fissures and deep cracks in the skin can form due to significant xerosis (Fig. 1h). Fissures and skin cracking are termed rhagades in the European literature [73]. They often occur in the fingertips, in the palms or knuckles, and in the 
Table 8 Xerosis recommendations

\begin{tabular}{|c|c|c|c|c|c|}
\hline & Recommend & $\begin{array}{l}\text { Not } \\
\text { recommended }\end{array}$ & $\begin{array}{l}\text { Level of } \\
\text { evidence }\end{array}$ & $\begin{array}{l}\text { Recommendation } \\
\text { grades }\end{array}$ & Comments \\
\hline \multicolumn{6}{|l|}{ Preventive } \\
\hline Topical & $\begin{array}{l}\text { Bathing techniques using bath oils } \\
\text { or mild moisturizing soaps and } \\
\text { bathing in tepid water } \\
\text { Regular moisturizing creams }\end{array}$ & & III & $\mathrm{B}$ & \\
\hline Other & $\begin{array}{l}\text { Avoid extreme temperatures } \\
\text { and direct sunlight }\end{array}$ & & III $^{\mathrm{a}}$ & B & \\
\hline \multicolumn{6}{|l|}{ Treatment } \\
\hline \multirow[t]{2}{*}{$\begin{array}{l}\text { Topical } \\
\text { (mild/ } \\
\text { moderate) }\end{array}$} & $\begin{array}{l}\text { Emollient creams that are packaged } \\
\text { in a jar/tub that lack fragrances or } \\
\text { potential irritants }\end{array}$ & $\begin{array}{l}\text { Alcohol- } \\
\text { containing } \\
\text { lotions }\end{array}$ & III & B & $\begin{array}{l}\text { More greasy creams for use } \\
\text { on the limbs, but caution } \\
\text { use of greasy creams on the } \\
\text { face and chest }\end{array}$ \\
\hline & $\begin{array}{l}\text { Occlusive emollients containing urea, } \\
\text { colloidal oatmeal, and petroleum-based } \\
\text { creams } \\
\text { For scaly areas, use exfoliants: ammonium } \\
\text { lactate } 12 \% \text { or lactic acid cream } 12 \% \\
\text { Urea creams }(10-40 \%) \\
\text { Salicylic acid } 6 \% \\
\text { Zinc oxide }(13-40 \%)\end{array}$ & $\begin{array}{l}\text { Retinoids or } \\
\text { benzoyl } \\
\text { peroxide }\end{array}$ & & & $\begin{array}{l}\text { Exfoliants may sting or burn } \\
\text { when applied to eroded or } \\
\text { erythematous skin-apply } \\
\text { only on intact skin }\end{array}$ \\
\hline $\begin{array}{l}\text { Topical } \\
\text { (severe) }\end{array}$ & $\begin{array}{l}\text { Medium- to high-potency steroid creams } \\
\text { (triamcinolone acetonide } 0.025 \% \text {; deso- } \\
\text { nide } 0.05 \% \text {; fluticasone proprionate } \\
0.05 \% \text {; alclometasone } 0.05 \% \text { ) }\end{array}$ & & III & $\mathrm{B}$ & \\
\hline
\end{tabular}

${ }^{\mathrm{a}}$ EGFRI study

soles-like xerosis, they are a late side effect of EGFRI therapy, occurring around 30-60 days into therapy [19, 36]. They can be very painful and create risk for infection. As with xerosis, there is no randomized clinical trial data supporting prevention or treatment guidelines for EGFRIinduced fissures. All recommendations are based on case studies, observation, and expert opinion, as well as dermatologic studies from the noncancer population.

Table 9 displays the recommendations for the prevention and treatment of fissures. Wearing protective footwear or covering the fingertips to avoid friction can prevent skin fissures and aid healing. Treatment for skin fissures varies, with many recommendations. Thick moisturizers or zinc oxide creams can be applied. Bleach soaks can prevent infection, with a dilution rate of one quarter cup of bleach to 3 gal of water [34]. Liquid glues like cyanoacrylate preparations (Superglue ${ }^{\circledR}$ or Liquid Bandaid ${ }^{\circledR}$ ) can be used to seal the cracks and keep them from worsening or becoming infected [21, 34, 68, 74]. Sealing the cracks with these products can also help relieve pain and allow for healing $[21,74]$. Propylene glycol $50 \%$ solution and salicylic acid $10 \%$ ointment are other recommendations $[1,34,67$, 75]. Steroid tape (Cordran tape ${ }^{\circledR}$ ) and hydrocolloid dressings are recommended for painful, erythematous areas $[34,68$,
73]. Limited evidence also supports the use of silver nitrate or potassium permanganate foams and topical antibiotics [38]. Oral antibiotics may be necessary if infection worsens despite topical treatment.

\section{Paronychia}

All patients receiving EGFRIs are at risk for developing nail changes, which typically develop after two or more months of chemotherapy exposure [22, 76-80]. The most commonly seen nail changes include nail fold inflammation (paronychia) and periungual pyogenic granuloma-like lesions (Fig. 1i). Resultant onycholysis or onychodystrophy may result as a secondary process from the presence of nail matrix inflammation.

Paronychia is characterized by tender, edematous, often purulent inflammation of the nail folds. Fingernails and toenails may be affected, with the first digits most commonly affected. Precedent trauma is not believed to be causative but rather an aggravating factor. Morbidity is high, leading to significant pain, functional limitation, and impairment of activities of daily living. Periungual pyogenic granulomata are characterized by friable vascular tissue overgrowths on lateral nail folds. Easy bleeding is a 
Table 9 Fissure recommendations

\begin{tabular}{|c|c|c|c|c|c|}
\hline & Recommend & $\begin{array}{l}\text { Not } \\
\text { recommended }\end{array}$ & $\begin{array}{l}\text { Level of } \\
\text { evidence }\end{array}$ & $\begin{array}{l}\text { Recommendation } \\
\text { grades }\end{array}$ & Comments \\
\hline \multicolumn{6}{|c|}{ Preventive } \\
\hline Topical & $\begin{array}{l}\text { Wear protective footwear and avoid friction with } \\
\text { fingertips, toes, and heals }\end{array}$ & & III & $\mathrm{B}$ & \\
\hline \multicolumn{6}{|c|}{ Treatment } \\
\hline Topical & $\begin{array}{l}\text { Thick moisturizers or zinc oxide }(13-40 \%) \text { creams } \\
\text { Liquid glues or cyanoacrylate to seal cracks } \\
\text { Steroids or steroid tape, hydrocolloid } \\
\text { dressings, topical antibiotics } \\
\text { Bleach soaks to prevent infection } \\
\text { Zinc oxide }\end{array}$ & & $\mathrm{III}^{\mathrm{a} / \mathrm{b}}$ & B & $\begin{array}{l}\text { Cream application often } \\
\text { impractical }\end{array}$ \\
\hline
\end{tabular}

${ }^{\text {a }}$ EGFRI study

${ }^{\mathrm{b}}$ Non-EGFRI cancer treatment study

common complaint. Increased local trauma is believed to be an aggravating factor in inciting lesion development. The mechanism for these vascular overgrowths is unclear, but it is hypothesized to be related to EGFRI interruption of retinoic acid metabolism [81].

There are no approved treatments for EGFRI-associated nail changes. Similarly, there have been no randomized controlled studies evaluating therapies for paronychia. Recommendations are based on expert opinion and anecdotal reports and Table 10 displays the recommendations for the prevention and treatment of paronychia. Much of our knowledge comes from prior experience with drug-induced paronychia and periungual pyogenic granulomata, most notably from high-dose systemic retinoid therapy and indinavir (human immunodeficiency virus protease inhibitor) [82, 83].

Paronychia is a sterile process, but it has the potential to become superinfected. Culturing of lesional skin to determine if superinfection is present is universally recommended so that antimicrobials can be directed accordingly [84]. A retrospective study of 152 patients treated with cetuximab revealed 27 instances of paronychia (incidence of 17.7\%). A total of 42 culture swabs were performed in which all grew some organisms. The rate of coagulase-negative gram-positive bacteria (nosocomial colonization) was $31 \%$, which was higher than the rate of $S$. aureus infection (23\%) [85].

Management strategies are aimed at minimizing periungual trauma, decreasing periungual inflammation, preventing superinfection, and eliminating excessive granulation tissue. Wearing comfortable shoes, trimming nails but avoiding aggressive manicuring, and wearing gloves while cleaning (e.g., household, dishes) are recommended to minimize periungual trauma. Biotin has been found effective for the treatment of brittle nails in the general population [86]. Topical corticosteroid and anti-inflammatory dose tetracycline to decrease periungual inflammation and antimicrobial soaks (e.g., dilute bleach in water; dilute white vinegar in water) to prevent superinfection are recommended [87-97]. Additionally, electrocautery, silver nitrate, and nail avulsion also are recommended to eliminate excessive granulation tissue $[98,99]$.

Correlation of rash and therapeutic response

One of the observations made by early clinical investigators was the correlation between the development of rash and response to EGFRI therapy [100]. Clearly, this was an important observation because, if rash proved to be a clinical marker for response, it would offer patients a motivating factor to work through the rash associated with the first 2 months of therapy in order to establish drug efficacy.

There are several methodological issues that must be noted when interpreting the data addressing this question. First, for most of the reported studies, the primary outcome parameter was either response to therapy or overall survival. Reporting of toxicities was a secondary aim; thus, data collection has been largely passive by spontaneous report. Passive data collection is believed to lead to underreporting [101]. In addition, most clinical researchers are not well versed in the assessment of dermatologic toxicity. Finally, most clinical trials use toxicity assessment scoring systems that are rather blunt outcome measures.

Although mixed, the bulk of data would tend to support the correlation between rash and outcomes in patients treated with EGFRI therapy. Positive correlations between rash and outcome have been reported in studies using cetuximab [102, 103], erlotinib [104, 105], gefitinib [106, 107], and panitumumab [108]. Data support not only an increase in response but an increase in survival for those patients experiencing a rash [102-107]. Although less robust, there is also data to support that increasing severity 
of rash is correlated with increasing response and survival [109]. These correlations appear across tumor types including head and neck [104, 107], lung [105, 106], and colorectal cancer $[102,103]$. Conversely, there have been a small number of studies that fail to correlate rash response with outcome. In a 1,037 patient trial comparing paclitaxel and carboplatin to paclitaxel, carboplatin, and gefitinib, no correlation between rash and survival was seen. It should be noted that this was a negative trial and that gefitinib failed to improve outcome, thus obviating the potential predictive benefit of rash [110].

\section{Summary and discussion}

Specific recommendations for preventative and reactive interventions for EGFRI-associated dermatologic toxicities are proposed herein. Patients should be educated about these potential dermatological events before receiving EGFRIs and, where possible, be encouraged to use preventive measures. Regardless of strategy, patient education prior to EGFRI therapy is critical in order to ensure anticipatory coping, in which expectancy and preparation for dermatologic changes allows patients not only to cope but also to overcome the significant decrement to HQOL posed by the toxicity (see Patient Education Brochure in the Electronic supplementary material).
In addition to specific recommendations, we propose that multidisciplinary teams including radiation oncologists, nurses, medical oncologists, dermatologists, pharmacists, oral health care provider, and wound care specialists should assess the occurrence and management of EGRFI-associated dermatologic toxicities. Universal recommendations for certain toxicities are not possible; therefore, it is vital that the treatment team seek input from wound care specialists, oral health care providers, and dermatologists for specific and severe toxicities. Furthermore, oncologists need to know how to address commonly seen issues and to establish a referral pattern with a dermatologist or oral health care provider with an oncology area of focus.

Recommendations were based on randomized clinical trials with control groups when possible; but, as mentioned previously, the lack of quality studies investigating EGFRIassociated dermatologic toxicities necessitates that many recommendations be based on expert opinion and consensus. For most of the EGFRI-associated dermatologic toxicities, it is unlikely that large randomized clinical trials will be conducted to investigate management options. That being said, important information may be garnered from treatment trials utilizing EGFRIs either alone or in combination. We would, therefore, recommend that dermatologic toxicities be documented in a consistent and thorough manner in all future studies of EGFRIs.

Table 10 Paronychia recommendations

\begin{tabular}{|c|c|c|c|c|c|}
\hline & Recommend & Not recommended & $\begin{array}{l}\text { Level of } \\
\text { evidence }\end{array}$ & $\begin{array}{l}\text { Recommendation } \\
\text { grades }\end{array}$ & Comments \\
\hline \multicolumn{6}{|l|}{ Preventive } \\
\hline Topical & $\begin{array}{l}\text { Diluted bleach soaks } \\
\text { Avoid irritants }\end{array}$ & & $\mathrm{II}^{\mathrm{a}}$ & A & $\begin{array}{l}\text { Recommend final concentration } \\
\text { of approximately } 0.005 \% \\
\text { (approximately } 1 / 4-1 / 8 \text { cup } \\
\text { of } 6 \% \text { bleach for } 3-5 \text { gal water) }\end{array}$ \\
\hline \multicolumn{6}{|l|}{ Treatment } \\
\hline Topical & $\begin{array}{l}\text { Corticosteroids } \\
\text { Calcineurin inhibitors }\end{array}$ & $\begin{array}{l}\text { Antifungals } \\
\text { Antibiotics }\end{array}$ & $\mathrm{II}^{\mathrm{a}}$ & A & $\begin{array}{l}\text { Recommend usage of ultrapotent } \\
\text { topical steroids as first-line therapy } \\
\text { given cost and availability of these } \\
\text { agents }\end{array}$ \\
\hline \multirow[t]{2}{*}{ Systemic } & Tetracyclines & $\begin{array}{l}\text { Empiric antibiotics- } \\
\text { employed without culturing } \\
\text { lesional skin }\end{array}$ & $\mathrm{IV}^{\mathrm{b}} / \mathrm{II}^{\mathrm{a}}$ & $\mathrm{D} / \mathrm{A}$ & \\
\hline & $\begin{array}{l}\text { Antimicrobials: reserved } \\
\text { for culture proven } \\
\text { infection }\end{array}$ & Antifungals & & & \\
\hline Systemic & Biotin for brittle nails & & $\mathrm{III}^{\mathrm{a}}$ & $\mathrm{B}$ & \\
\hline Other & $\begin{array}{l}\text { Silver nitrate chemical } \\
\text { cauterization weekly } \\
\text { Electrodessication } \\
\text { Nail avulsion }\end{array}$ & & $\mathrm{IV}^{\mathrm{a}}$ & $\mathrm{D}$ & $\begin{array}{l}\text { Reserved for pyogenic granulomata; } \\
\text { cnsensus of experts }\end{array}$ \\
\hline
\end{tabular}

${ }^{a}$ Non-EGFRI noncancer treatment study

${ }^{\mathrm{b}}$ EGFRI study 
One of the problems hindering the effective reporting and management of EGFRI-associated dermatologic toxicities is the use of varied, inconsistent toxicity criteria. To this end, the Skin Toxicity Group proposed the use of the MASCC EGFRI Skin Toxicity Tool (MESTT) [111] in clinical trials and in clinical practice [for the website to download the MESTT, see 112]. Although clinical trials often use the Common Terminology Criteria for Adverse Events (NCICTCAE) version 4.03 [113], this tool was not designed for reporting EGFRI-associated dermatological events. The MESTT is a more precise tool that can address the current state of underreporting and inadequate assessment of these dermatologic adverse events. In fact, a recent study has demonstrated that, while the grades of MESTT and CTCAE are well correlated, the CTCAE tends to underreport the severity of some of the dermatologic side events which can lead to the under adjustment/discontinuation of treatment [114]. However, even with the use of standardized criteria, grading of reactions remains somewhat subjective and this may impede the comparison of toxicity findings between clinical studies. An additional way to minimize discrepancy is to document dermatologic toxicity photographically, thus enabling subsequent independent confirmation of grading where necessary. It is recommended that digital photographic documentation be adopted as a standard practice in clinical trials.

In summary, the mechanism of dermatologic toxicities attributed to targeted therapies requires the assessment of mechanistically directed interventions for prevention and management. A greater understanding of the biological mechanisms responsible for the toxicity of the individual agents would lead to the development of rational and more effective management strategies for the dermatologic reactions of patients receiving radiotherapy and EGFRIs.

Conflict of interest statement This project was supported by unrestricted grants from Bristol-Myers Squibb, Evolife, OSI Pharmaceuticals, Inc., and Amgen, Inc. Sponsors did not contribute to the development of this manuscript. M.E.L. is supported by a Dermatology Foundation Career Development Award and receives funding from Hana Biosciences. M.E.L. serves as a consultant/advisory role to Bristol-Myers Squibb, Pfizer, OSI Pharmaceuticals, Inc., Genentech, Inc., Eli Lilly, Amgen, Inc., AZ, and Boehringer Ingelheim. M.J.A. serves as a consultant/advisory role to Bristol-Myers Squibb and Imclone. R.J.B. serves as a consultant/ advisory role to Amgen, Inc. A.C. serves as a consultant/advisory role and receives research funding from Merck, Sharp, and Dohme Corporation. B. E.S serves on the Speakers Bureau for Genentech, Inc.

\section{References}

1. Balagula Y, Garbe C, Myskowski P, Hauschild A, Rapoport B, Boers-Doets CB, Lacouture ME (2011) Clinical presentation and management of dermatological toxicities of epidermal growth factor receptor inhibitors. Int J Dermatol 50:129-146
2. Boone SL, Rademaker A, Liu D, Pfeiffer C, Mauro DJ, Lacouture ME (2007) Impact and management of skin toxicity associated with anti-epidermal growth factor receptor therapy: survey results. Oncology 72(3-4):152-159

3. Somerfield M, Padberg J, Pfister D et al (2000) ASCO clinical practice guidelines: process, progress, pitfalls, and prospects. Classic Papers Curr Comments 4:881-886

4. Lacouture ME (2006) Mechanisms of cutaneous toxicities to EGFR inhibitors. Nat Rev Cancer 6(10):803-812

5. Hassel JC, Kripp M, Al-Batran S, Hofheinz RD (2010) Treatment of epidermal growth factor receptor antagonist-induced skin rash: results of a survey among German oncologists. Onkologie 33 (3):94-98

6. Jatoi A, Dakhil SR, Sloan JA, Kugler JW, Rowland KM Jr, Schaefer PL, Novotny PJ, Wender DB, Gross HM, Loprinzi CL (2010) Prophylactic tetracycline does not diminish the severity of epidermal growth factor receptor (EGFR) inhibitor-induced rash: results from the North Central Cancer Treatment Group (Supplementary N03CB). Support Care Cancer (in press)

7. Jatoi A, Thrower A, Sloan JA, Flynn PJ, Wentworth-Hartung NL, Dakhil SR, Mattar BI, Nikcevich DA, Novotny P, Sekulic A, Loprinzi CL (2010) Does sunscreen prevent epidermal growth factor receptor (EGFR) inhibitor-induced rash? Results of a placebo-controlled trial from the North Central Cancer Treatment Group (N05C4). Oncologist 15(9):1016-1022

8. Jatoi A, Rowland K, Sloan JA, Gross HM, Fishkin PA, Kahanic SP, Novotny PJ, Schaefer PL, Johnson DB, Tschetter LK, Loprinzi CL (2008) Tetracycline to prevent epidermal growth factor receptor inhibitor-induced skin rashes: results of a placebo-controlled trial from the North Central Cancer Treatment Group (N03CB). Cancer 113(4):847-853

9. Scope A, Lieb JA, Dusza SW, Phelan DL, Myskowski PL, Saltz L, Halpern AC (2009) A prospective randomized trial of topical pimecrolimus for cetuximab-associated acnelike eruption. J Am Acad Dermatol 61(4):614-620

10. Lacouture ME, Mitchell EP, Piperdi B, Pillai MV, Shearer H, Iannotti N, Xu F, Yassine M (2010) Skin toxicity evaluation protocol with panitumumab (STEPP), a phase II, open-label, randomized trial evaluating the impact of a pre-Emptive Skin treatment regimen on skin toxicities and quality of life in patients with metastatic colorectal cancer. J Clin Oncol 28(8):1351-1357

11. Scope A, Agero AL, Dusza SW, Myskowski PL, Lieb JA, Saltz L, Kemeny NE, Halpern AC (2007) Randomized double-blind trial of prophylactic oral minocycline and topical tazarotene for cetuximab-associated acne-like eruption. J Clin Oncol 25 (34):5390-5396

12. Katzer K, Tietze J, Klein E, Heinemann V, Ruzicka T, Wollenberg A (2010) Topical therapy with nadifloxacin cream and prednicarbate cream improves acneiform eruptions caused by the EGFR-inhibitor cetuximab - a report of 29 patients. Eur J Dermatol 20(1):82-84

13. Perez-Soler R, Zou Y, Li T, Tornos C, Ling Y (2006) Topical vitamin K3 (Vit K3, Menadione) prevents erlotinib and cetuximab-induced EGFR inhibition in the skin. J Clin Oncol ASCO Annual Meeting Proceedings part I, vol. 24, no. 18S (June 20 Supplement)

14. Radovics N, Kornek G, Thalhammer F, Weihsengruber F, Pietrzak C, Resch G, Petzer AL, Hauser I, Wogritsch C, Greil R (2010) Analysis of the effects of vitamin K1 cream on cetuximab-induced acne-like rash. J Clin Oncol ASCO Annual Meeting Proceedings (Post-Meeting Edition) 28:15S (May 20 Supplement)

15. Bidoli P, Cortinovis DL, Colombo I, Crippa A, Cicchiello F, Villa F, Cazzaniga ME, Altomare G (2010) Isotretinoin plus clindamycin seem highly effective against severe erlotinib-induced skin rash in advanced non-small cell lung cancer. J Thorac Oncol 5(10):16621663 
16. Vezzoli P, Marzano AV, Onida F, Alessi E, Galassi B, Tomirotti M, Berti E (2008) Cetuximab-induced acneiform eruption and the response to isotretinoin. Acta Derm Venereol 88(1):84-86

17. Gutzmer R, Werfel T, Mao R, Kapp A, Elsner J (2005) Successful treatment with oral isotretinoin of acneiform skin lesions associated with cetuximab therapy. Br J Dermatol 153 (4):849-851

18. Olsen EA, Whiting D, Bergfeld W, Miller J, Hordinsky M, Wanser R, Zhang P, Kohut B (2007) A multicenter, randomized, placebo-controlled, double-blind clinical trial of a novel formulation of 5\% minoxidil topical foam versus placebo in the treatment of androgenetic alopecia in men. J Am Acad Dermatol 57(5):767-774

19. Olsen EA, Dunlap FE, Funicella T, Koperski JA, Swinehart JM, Tschen EH, Trancik RJ (2002) A randomized clinical trial of 5\% topical minoxidil versus $2 \%$ topical minoxidil and placebo in the treatment of androgenetic alopecia in men. J Am Acad Dermatol 47(3):377-385

20. Lucky AW, Piacquadio DJ, Ditre CM, Dunlap F, Kantor I, Pandya AG, Savin RC, Tharp MD (2004) A randomized, placebo-controlled trial of $5 \%$ and $2 \%$ topical minoxidil solutions in the treatment of female pattern hair loss. J Am Acad Dermatol 50(4):541-553

21. Burtness B, Anadkat M, Basti S et al (2009) NCCN Task Force Report: management of dermatologic and other toxicities associated with EGFR inhibition in patients with cancer. J Natl Compr Canc 7(S1):s5-s21

22. Ocvirk J, Cencelj S (2010) Management of cutaneous side-effects of cetuximab therapy in patients with metastatic colorectal cancer. JEADV 24:453-459

23. Hoffmann R (2008) A 4-month, open-label study evaluating the efficacy of eflornithine $11.5 \%$ creamin the treatment of unwanted facial hair in women using TrichoScan. Eur J Dermatol 18 (1):65-70

24. Jackson J, Caro JJ, Caro G, Garfield F, Huber F, Zhou W, Lin CS, Shander D, Schrode K, Eflornithine $\mathrm{HCl}$ Study Group (2007) The effect of eflornithine $13.9 \%$ cream on the bother and discomfort due tohirsutism. Int J Dermatol 46(9):976-981

25. Amin SP, Goldberg DJ (2006) Clinical comparison of four hair removal lasers and light sources. J Cosmet Laser Ther 8(2):6568

26. Hamzavi I, Tan E, Shapiro J, Lui H (2007) A randomized bilateral vehicle-controlled study of eflornithine cream combined with laser treatment versus laser treatment alone for facial hirsutism in women. J Am Acad Dermatol 57(1):54-59

27. Smith SR, Piacquadio DJ, Beger B, Littler C (2006) Eflornithine cream combined with laser therapy in the management of unwanted facial hair growth in women: a randomized trial. Dermatol Surg 32(10):1237-1243

28. Common Terminology Criteria for Adverse Events v3.0 (CTCAE). Available at http://ctep.cancer.gov/forms/CTCAEv3.pdf

29. Campbell IR, Illingworth MH (1992) Can patients wash during radiotherapy to the breast or chest wall? A randomized controlled trial. Clin Oncol (R Coll Radiol) 4:78-82

30. Roy I, Fortin A, Larochelle M (2001) The impact of skin washing with water and soap during breast irradiation: a randomized study. Radiother Oncol 58:333-339

31. Salvo N, Barnes E, van Draanen J, Stacey E, Mitera G, Breen D, Giotis A, Czarnota G, Pang J, De Angelis C (2010) Prophylaxis and management of acute radiation-induced skin reactions: a systematic review of the literature. Curr Oncol 17(4):94-112

32. Miller RC, Schwartz DJ, Sloan JA, Griffin PC, Deming RL, Anders JC, Stoffel TJ, Haselow RE, Schaefer PL, Bearden JD 3rd, Atherton PJ, Loprinzi CL, Martenson JA (2010) Mometasone furoate effect on acute skin toxicity in breast cancer patients receiving radiotherapy: a phase III double-blind, randomized trial from the North Central Cancer Treatment Group N06C4. Int J Radiat Oncol Biol Phys 79:1460-1466

33. Elliott EA, Wright JR, Swann RS et al (2006) Phase III trial of an emulsion containing trolamine for the prevention of radiation dermatitis in patients with advanced squamous cell carcinoma of the head and neck: results of Radiation Therapy Oncology Group Trial 99-13. J Clin Oncol 24:2092-2097

34. Aygenc E, Celikkanat S, Kaymakci M et al (2004) Prophylactic effect of pentoxifylline on radiotherapy complications: a clinical study. Otolaryngol Head Neck Surg 130:351-356

35. Lin LC, Que J, Lin LK, Lin FC (2006) Zinc supplementation to improve mucositis and dermatitis in patients after radiotherapy for head-and-neck cancers: a double-blind, randomized study. Int J Radiat Oncol Biol Phys 65:745-750

36. Segaert S, Van Cutsem E (2005) Clinical signs, pathophysiology and management of skin toxicity during therapy with epidermal growth factor receptor inhibitors. Ann Oncol 16:1425-1433

37. Segaert S, Tabernero J, Chosidow O et al (2005) The management of skin reactions in cancer patients receiving epidermal growth factor receptor targeted therapies. J Dtsch Dermatol Ges 3:599-606

38. Roé E, García Muret MP, Marcuello E, Capdevila J, Pallarés C, Alomar A (2006) Description and management of cutaneous side effects during cetuximab or erlotinib treatments: a prospective study of 30 patients. J Am Acad Dermatol 55:429-437

39. Racca P, Fanchini L, Caliendo V et al (2008) Efficacy and skin toxicity management with cetuximab in metastatic colorectal cancer: outcomes from an Oncologic/Dermatologic Cooperation. Clin Colorectal Cancer 7:48-54

40. Monroe EW, Bernstein DI, Fox RW et al (1992) Relative efficacy and safety of loratadine, hydroxyzine, and placebo in chronic idiopathic urticaria. Arzneimittelforschung 42:11191121

41. Monroe EW (1992) Relative efficacy and safety of loratadine, hydroxyzine, and placebo in chronic idiopathic urticaria and atopic dermatitis. Clin Ther 14(1):17-21

42. Porzio G, Aielli F, Verna L, Porto C, Tudini M, Cannita K, Ficorella C (2006) Efficacy of pregabalin in the management of cetuximab-related itch. J Pain Symptom Manage 32:397-398

43. Goutos I, Eldardiri M, Khan AA, Dziewulski P, Richardson PM (2010) Comparative evaluation of antipruritic protocols in acute burns. The emerging value of gabapentin in the treatment of burns pruritus. J Burn Care Res 31(1):57-63

44. Gunal AI, Ozalp G, Yoldas TK, Gunal SY, Kirciman E, Celiker $\mathrm{H}$ (2004) Gabapentin therapy for pruritus in haemodialysis patients: a randomized, placebo-controlled, double-blind trial. Nephrol Dial Transplant 19(12):3137-3139

45. Vincenzi B, Tonini G, Santini D (2010) Aprepitant for erlotinibinduced pruritus. N Engl J Med 363:397-398

46. Bromm B, Scharein E, Darsow U, Ring J (1995) Effects of menthol and cold on histamine-induced itch and skin reactions in man. Neurosci Lett 187:157-160

47. Drake LA, Millikan LE (1995) The antipruritic effect of 5\% doxepin cream in patients with eczematous dermatitis. Doxepin Study Group. Arch Dermatol 131(12):1403-1408

48. Shohrati M, Davoudi SM, Keshavarz S, Sadr B, Tajik A (2007) Cetirizine, doxepine, and hydroxyzine in the treatment of pruritus due to sulfur mustard: a randomized clinical trial. Cutan Ocul Toxicol 26(3):249-255

49. Pour-Reza-Gholi F, Nasrollahi A, Firouzan A, Nasli Esfahani E, Farrokhi F (2007) Low-dose doxepin for treatment of pruritus in patients on hemodialysis. Iran J Kidney Dis 1(1):34-37

50. Eschler DC, Klein PA (2010) An evidence-based review of the efficacy of topical antihistamines in the relief of pruritus. J Drugs Dermatol 9(8):992-997 
51. Yaffe SJ et al (1973) Antihistamine in topical preparations. Pediatrics 51:299-301

52. Khuntia D, Harris J, Bentzen SM et al (2008) Increased oral mucositis after IMRT versus non-IMRT when combined with cetuximab and cisplatin or docetaxel for head and neck cancer: preliminary results of RTOG 0234. Int J Radiat Oncol Biol Phys 72(1):S33

53. Motzer RJ, Amato R, Todd M et al (2003) Phase II trial of antiepidermal growth factor receptor antibody $\mathrm{C} 225$ in patients with advanced renal cell carcinoma. Invest New Drugs 21(1):99-101

54. Xiong HQ, Rosenberg A, LoBuglio A et al (2004) Cetuximab, a monoclonal antibody targeting the epidermal growth factor receptor, in combination with gemcitabine for advanced pancreatic cancer: a multicenter phase II trial. J Clin Oncol 22(13):2610 2616

55. Saltz LB, Meropol NJ, Loehrer PJ, Needle MN, Kopit J, Mayer RJ (2004) Phase II trial of cetuximab in patients with refractory colorectal cancer that expresses the epidermal growth factor receptor. J Clin Oncol 22(7):1201-1208

56. Reynolds NA, Wagstaff AJ (2004) Cetuximab - in the treatment of metastatic colorectal cancer. Drugs 64(1):109-118

57. Vermorken JB, Trigo J, Hitt R et al (2007) Open-label, uncontrolled, multicenter phase II study to evaluate the efficacy and toxicity of cetuximab as a single agent in patients with recurrent and/or metastatic squamous cell carcinoma of the head and neck who failed to respond to platinum-based therapy. J Clin Oncol 25(16):2171-2177

58. Belani CP, Schreeder MT, Steis RG et al (2008) Cetuximab in combination with carboplatin and docetaxel for patients with metastatic or advanced-stage nonsmall cell lung cancer: a multicenter phase 2 study. Cancer 113(9):2512-2517

59. Vermorken JB, Mesia R, Rivera F et al (2008) Platinum-based chemotherapy plus cetuximab in head and neck cancer. New Engl J Med 359(11):1116-1127

60. Thomas M (2005) Cetuximab: adverse event profile and recommendations for toxicitmanagement. Clin J Oncol Nurs 9 (3):332-338

61. Lenz HJ (2006) Anti-EGFR mechanism of action: antitumor effect and underlying cause of adverse events. Oncology 20(5 Suppl 2):5-13

62. Keefe DM, Schubert MM, Elting LS, St S, Epstein JB, Raber-Drulacher JE et al (2007) Updated clinical practice guidelines for the prevention and treatment of mucostis. Cancer 109(5):820-831

63. Rubenstein EB, Peterson DE, Schubert M, Keefe D, McGuire D, Epstein $\mathrm{J}$ et al (2004) Clinical practice guidelines for the prevention and treatment of cancer therapy-induced oral and gastrointestinal mucositis. Cancer 100(9):2026-2046

64. Epstein JB, Elad S, Eliav E, Jurevic R, Benoliel R (2007) Orofacial pain in cancer: part II: clinical perspectives and management. J Dent Res 86(6):506-518

65. Gorsky M, Epstein J, Raviv A, Yaniv R, Truelove E (2008) Topical minocycline for managing symptoms of recurrent aphthous stomatitis. Spec Care Dent 28(1):27-31

66. Gorsky M, Epstein JB, S1 R, Elishoov H, Yarom N (2007) Topical minocycline and tetracycline rinses in treatment of recurrent aphthous stomatitis: a randomized cross-over study. Dermatol Online J 13(2):1

67. Tsimboukis S, Merikas I, Karapanagiotou EM, Saif MW, Syrigos KN (2009) Erlotinib-induced skin rash in patients with nonsmall-cell lung cancer: pathogenesis, clinical significance, and management. Clin Lung Cancer 10(2):106-111

68. Hu JC, Sadeghi P, Pinter-Brown LC, Yashar S, Chiu MW (2007) Cutaneous side effects of epidermal growth factor receptor inhibitors: clinical presentation, pathogenesis, and management. J Am Acad Dermatol 56(2):317-326
69. Ricciardi S, Tomao S, de Marinis F (2009) Toxicity of targeted therapy in non-small-cell lung cancer management. Clin Lung Cancer 10(1):28-35

70. Saif MW, Kaley K, Lamb L, Pecerillo J, Hotchkiss S, Steven L, Brennan M, Penney R, Gillespie C, Shaib W (2010) Management of skin toxicities of anti-EGFR agents in patients with pancreatic cancer and other GI tumors by using electronic communication: effective and convenient. JOP 11 (2): $176-182$

71. Gutzmer R, Werfel T, Kapp A, Elsner J (2006) Cutaneous side effects of EGF-receptor inhibition and their management. Hautarzt 57(6):509-513

72. Pérez-Soler R, Delord JP, Halpern A, Kelly K, Krueger J, Sureda BM, von Pawel J, Temel J, Siena S, Soulières D, Saltz L, Leyden J (2005) HER1/EGFR inhibitor-associated rash: future directions for management and investigation outcomes from the HER1/ EGFR inhibitor rash management forum. Oncologist 10(5):345356

73. Wollenberg A, Kroth J, Hauschild A, Dirschka T (2010) Cutaneous side effects of EGFR inhibitors-appearance and management. Dtsch Med Wochenschr 135(4):149-154

74. Shah NT, Kris MG, Pao W, Tyson LB, Pizzo BM, Heinemann MH, Ben-Porat L, Sachs DL, Heelan RT, Miller VA (2005) Practical management of patients with non-small-cell lung cancer treated with gefitinib. J Clin Oncol 23(1):165-174

75. Jennings MB, Alfieri D, Ward K, Lesczczynski C (1998) Comparison of salicylic acid and urea versus ammonium lactate for the treatment of foot xerosis. A randomized, double-blind, clinical study. J Am Podiatr Med Assoc 88(7):332-336

76. Busam KJ, Capodieci P, Motzer R, Kiehn T, Phelan D, Halpern AC (2001) Cutaneous side-effects in cancer patients treated with the antiepidermal growth factor receptor antibody $\mathrm{C} 225$. Br J Dermatol 144(6):1169-1176

77. Becker A, van Wijk A, Smit EF, Postmus PE (2010) Side-effects of long-term administration of erlotinib in patients with nonsmall cell lung cancer. J Thorac Oncol 5(9):1477-1480

78. OSI Pharmaceuticals (2005) Tarceva package insert

79. ImClone Systems (2006) Erbitux package insert

80. Osio A, Mateus C, Soria JC, Massard C, Malka D, Boige V, Besse B, Robert C (2009) Cutaneous side-effects in patients on long-term treatment with epidermal growth factor receptor inhibitors. Br J Dermatol 161(3):515-521

81. Hong SH, Wong CW, Privalsky ML (1998) Signaling by tyrosine kinases negatively regulates the interaction between transcription factors and SMRT (silencing mediator of retinoic acid and thyroid hormone receptor) corepressor. Mol Endocrinol 12:1161-1171

82. Baran R (1986) Etretinate and the nails (study of 130 cases) possible mechanisms of some side-effects. Clin Exp Dermatol $11: 148-152$

83. Bouscarat F, Bouchard C, Bouhour D (1998) Paronychia and pyogenic granuloma of the great toes in patients treated with indinavir. N Engl J Med 338:1776-1777

84. Sassone LM, Fidel RA, Murad CF, Fidel SR, Hirata R Jr (2008) Antimicrobial activity of sodium hypochlorite and chlorhexidine by two different tests. Aust Endod J 34(1):19-24

85. Eames T, Grabein B, Kroth J, Wollenberg A (2010) Microbiological analysis of epidermal growth factor receptor inhibitor therapy-associated paronychia. J Eur Acad Dermatol Venereol 24 (8):958-960

86. Floersheim GL (1989) Treatment of brittle fingernails with biotin. Z Hautkr 64(1):41-48

87. Tosti A, Piraccini BM, Ghetti E, Colombo MD (2002) Topical steroids versus systemic antifungals in the treatment of chronic paronychia: an open, randomized double-blind and double dummy study. J Am Acad Dermatol 47(1):73-76 
88. Wollina U (2001) Acute paronychia: comparative treatment with topical antibiotic alone or in combination with corticosteroid. J Eur Acad Dermatol Venereol 15(1):82-84

89. Rao A, Bunker C (2010) Efficacy and safety of tacrolimus ointment $0.1 \%$ vs. betamethasone 17 -valerate $0.1 \%$ in the treatment of chronic paronychia: an unblinded randomized study. Br J Dermatol 163(1):208

90. Rigopoulos D, Gregoriou S, Belyayeva E, Larios G, Ontochristopoulos G, Katsambas A (2009) Efficacy and safety of tacrolimus ointment $0.1 \%$ vs. betamethasone 17 valerate $0.1 \%$ in the treatment of chronic paronychia: an unblinded randomized study. Br J Dermatol 160(4):858-860

91. Daniel CR 3rd, Daniel MP, Daniel CM, Sullivan S, Ellis G (1996) Chronic paronychia and onycholysis: a thirteen-year experience. Cutis 58:397-401

92. Rosenbaum D, Merenstein D, Meyer F (2002) Topical steroids more effective than antifungals for chronic paronychia. J Fam Pract 51:824

93. Roberts DT, Richardson MD, Dwyer PK, Donegan R (1992) Terbinafine in chronic paronychia and candida onychomycosis. $\mathrm{J}$ Derm Treat S1:39-42

94. Rutala WA, Weber DJ (1997) Uses of inorganic hypochlorite (bleach) in health-care facilities. Clin Microbiol Rev 10(4):597610

95. Shu KY, Kindler HL, Medenica M, Lacouture M (2006) Doxycycline for the treatment of paronychia induced by the epidermal growth factor receptor inhibitor cetuximab. $\mathrm{Br} \mathrm{J}$ Dermatol 154(1):191-192

96. Wilhelmi BJ, Calianos TA II, Appelt EA, Ortiz ME, Heggers JP, Phillips LG (1999) Modified Dakin's solution for cutaneous vibrio infections. Ann Plast Surg 43(4):386-389

97. Rutala WA, Cole EC, Thomann CA, Weber DJ (1998) Stability and bactericidal activity of chlorine solutions. Infect Control Hosp Epidemiol 19(5):323-327

98. Quitkin HM, Rosenwasser MP, Strauch RJ (2003) The efficacy of silver nitrate cauterization for pyogenic granuloma of the hand. J Hand Surg Am 28(3):435-438

99. Ghodsi SZ, Raziei M, Taheri A, Karami M, Mansoori P, Farnaghi F (2006) Comparison of cryotherapy and curettage for the treatment of pyogenic granuloma: a randomized trial. $\mathrm{Br} \mathrm{J}$ Dermatol 154(4):671-675

100. Saltz L, Rubin MS, Hochster H et al (2001) Acne-like rash predicts response in patients treated with cetuximab (IMC-C225) plus irinotecan (CPT-11) in CPT-11 refractory colorectal cancer (CRC) that expresses epidermal growth factor receptor. Clin Cancer Res 7:3766s (abstract 559)

101. Bentzen SM, Trotti A (2007) Evaluation of early and late toxicities in chemoradiation trials. J Clin Oncol 25(26):40964103

102. Lièvre A, Bachet JB, Boige V, Cayre A, Le Corre D, Buc E, Ychou M, Bouché O, Landi B, Louvet C, André T, Bibeau F, Diebold MD, Rougier P, Ducreux M, Tomasic G, Emile JF, Penault-Llorca F, Laurent-Puig P (2008) KRAS mutations as an independent prognostic factor in patients with advanced colorectal cancer treated with cetuximab. J Clin Oncol 26(3):374379
103. Lenz HJ, Van Cutsem E, Khambata-Ford S, Mayer RJ, Gold P, Stella P, Mirtsching B, Cohn AL, Pippas AW, Azarnia N, Tsuchihashi Z, Mauro DJ, Rowinsky EK (2006) Multicenter phase II and translational study of cetuximab in metastatic colorectal carcinoma refractory to irinotecan, oxaliplatin and fluropyrimidines. J Clin Oncol 24(30):4814-4921

104. Soulieres D, Senzer NN, Vokes EE, Hidalgo M, Agarwala SS, Siu LL (2004) Multicenter phase II study of erlotinib, an oral epidermal growth factor receptor tyrosine kinase inhibitor, in patients with recurrent or metastatic squamous cell cancer of the head and neck. J Clin Oncol 22(1):77-85

105. Jackman DM, Yeap BY, Lindeman NI, Fidias P, Rabin MS, Temel J, Skarin AT, Meyerson M, Holmes AJ, Borras AM, Freidlin B, Ostler PA, Lucca J, Lynch TJ, Johnson BE, Jänne PA (2007) Phase II clinical trial of chemotherapy-naive patients $\geq 70$ years of age treated with erlotinib for advanced non-small-cell lung cancer. J Clin Oncol 29(7):760-766

106. West HL, Franklin WA, McCoy J, Gumerlock PH, Vance R, Lau DH, Chansky K, Crowley JJ, Gandara DR (2006) Gefitinib therapy in advanced bronchioloalveolar carcinoma: Southwest Oncology Group Study S0126. J Clin Oncol 24(12):1807-1813

107. Cohen EE, Kane MA, List MA, Brockstein BE, Mehrotra B, Huo D, Mauer AM, Pierce C, Dekker A, Vokes EE (2005) Phase II trial of gefitinib $250 \mathrm{mg}$ po daily in patients with recurrent and/or metastatic squamous cell carcinoma of the head and neck. Clin Cancer Res 11(23):8418-8424

108. Meropol NJ, Berlin J, Hecht JR et al (2003) Multicenter study of ABX-EGF monotherapy in patients with metastatic colorectal cancer. Proc Am Soc Clin Oncol 22:256

109. Pérez-Soler R, Chachoua A, Hammond LA, Rowinsky EK, Huberman M, Karp D, Rigas J, Clark GM, Santabárbara P, Bonomi P (2004) Determinants of tumor response and survival with erlotinib in patients with non-small-cell lung cancer. J Clin Oncol 22(16):3238-3247

110. Herbst RS, Giaccone G, Schiller JH, Natale RB, Miller V, Manegold C, Scagliotti G, Rosell R, Oliff I, Reeves JA, Wolf MK, Krebs AD, Averbuch SD, Ochs JS, Grous J, Fandi A, Johnson DH (2004) Gefitinib in combination with paclitaxel and carboplatin in advanced non-small-cell lung cancer: a phase III trial-INTACT 2. J Clin Oncol 22(5):785-794

111. Lacouture ME, Maitland ML, Segaert S, Setser A, Baran R, Fox LP, Epstein JB, Barasch A, Einhorn L, Wagner L, West DP, Rapoport BL, Kris MG, Basch E, Eaby B, Kurtin S, Olsen EA, Chen A, Dancey JE, Trotti A (2010) A proposed EGFR inhibitor dermatologic adverse event-specific grading scale from the MASCC skin toxicity study group. Support Care Cancer 18:509-522

112. MASCC EGFR Inhibitor Skin Toxicity Tool (MESTT). Available at http://www.mascc.org/mc/page.do?sitePageld $=98483$

113. NCI Common Terminology Criteria for Adverse Events v4.03 (CTCAE). Available at http://evs.nci.nih.gov/ftp1/CTCAE/ CTCAE 4.03 2010-06-14 QuickReference 8.5x11.pdf

114. Chan A, Tan EH (2010) How well does the MESTT correlate with CTCAE scale for the grading of dermatological toxicities associated with oral tyrosine kinase inhibitors? Support Care Cancer (in press) 